\title{
A Survey of the Hygienic Quality of Market Foods in Kandy
}

\author{
CHANDRA P. KODIKARA, P. SILVA \\ Faculty of Veterinary Medicine and Animal Science, University of Peradeniya, \\ Peradeniya, Sri Lanka. \\ AND
}

D. S. ATURALIYA

Municipal Veterinary Office, Kandy, Sri Lanka.

(Date of receipt : 28 February 1983)

(Date of acceptance : 30 January 1984)

\begin{abstract}
A total of 183 samples of consumable items of food and drink exposed for sale in the Kandy Municipal area were subjected to bacteriological examination with regard to its hygienic quality. Only 19 per cent of the samples of ice cream examined were within the limits of the bacteriological standards laid down by the Sri Lanka Bureau of Standards. Other desserts (Fruit salad, Wood-apple cream) show lower mean bacterial densities (Escherichia coli I, faecal streptococci and total viable count) than ice cream. The levels of faecal contamination of the fruit drinks did not vary with the place of preparation. This was due to the low $\mathrm{pH}$. The faecal streptococci appears to be better indicator of faecal contamination than $E$. coli type 1 uncicr freezing and at low
$\mathrm{pH}$.
\end{abstract}

\section{Introduction}

Diarrhoeal disease due to consumption of unhygienic food is a common feature among the population of Sri Lanka. The enteric disease agent once it enters food, usesit as a medium for dissemination.

The control of the food borne diseases could be effected on application of correct control measures at the most appropriate link in the epidemiological chain of events leading to disease. A knowledge of the critical control points in the food processing and distribution system is required for such a control.

A previous study on the bacteriological quality of ice cream in the city of Colombo has shown the hygienic quality to be very poor. ${ }^{4}$

The present study was carried out within the limits of the Kandy Municipal Council to determine the hygienic quality of food served to the public within this area.

\section{Experimental}

\subsection{Sampling and Preparation of Samples}

A total of 183 samples of food were examined. The food under investigation included products such as ice cream (42), other desserts such as fruit salad, watalappan, etc (26), diluted fruit drinks (34), pastries (37) and fermented milk products (44). The samples 
of ice cream investigated were from large and small scale producers. The small scale producer exposed their own ice cream for consumption within the premises. Samples of diluted fruit drinks included those prepared and sold in reputed establishments and on the pavement.

Collection of all products were done with the assistance of the Food Inspector, Kandy Municipal Council. Sterile precautions were taken during the opening of the packages and collection of samples. Representative samples of the food under investigation were obtained and examined within one hour of collection. Data pertaining to the manufacturer, date of manufacture were recorded.

Solid food were minced and 10 grams of the sample were shaken with $90 \mathrm{ml}$ of sterile normal saline. Decimal dilutions of liquid food were directly prepared in sterile normal saline down to $10-8$.

\subsection{Bacteriological Analysis}

In the enumeration of Escherichia coli I and coliforms, Violet Red Bile Agar (B B L 11807) was used. One $\mathrm{ml}$ of the sample and dilutions respectively were inoculated using the standard pour plate method. Incubation of the inoculated plate at $37^{\circ} \mathrm{C}$ was carried out to determine the number of coliforms. Similarly at $44^{\circ} \mathrm{C}$ to determine the number of $E$. coli $I$. The spread plate method using Slanetz and Bartley medium (MERCK 5262 ) at $37^{\circ} \mathrm{C}$ was employed to enumerate faecal streptococci. Plate count agar (Oxoid $\mathrm{C}$ M 325) was used to determine the total viable count at $30^{\circ} \mathrm{C}$. The pour plate method was employed using $1 \mathrm{ml}$ amounts of the samples and the decimal dilutions.

To determine the presence of Salmonella, approximately $10 \mathrm{ml}$ or 10 grams of the sample was incubated in a selective enrichment broth (PREUSS Potassium tetrathionate broth, Merck No. 5173 ) at $37^{\circ} \mathrm{C}$ for 16 hours followed by cultivation on solid selective media, Brilliant green lactose saccharose agar (Merk No. 7237) at $37^{\circ} \mathrm{C}$. Suspicious colonies were confirmed by biochemical and serological tests.

\section{Results}

Results show that there are marked differences in the three indicator densities, the coliforms, E. coli $I$ and faecal streptococci in the different types of food.

Of the 42 samples of ice cream examined,only 19 per cent were free of $E$. coli $I$. These were from reputed large scale manufacturers. The balance 81 per cent of the samples were mainly from the small scale producers where the consumption was within the place of manufacture.

The results in Table 1 indicates the number of samples and the percentage of the same, that belong to each category of indicator densities tested, namely $<10,11-100$, 101-1000 and >1000 per $\mathrm{ml}$ of ice cream. 
Table 1. Numbers of samples of different foods containing the indicators of contamination in the 4 categories $(<10,11-100,101-1000$ and $>1000$ per $\mathrm{gm}$ or $\mathrm{ml})$ indicated)

Number of samples in the 4 categories

Food

Total No. Type of of samples Indicator

$\begin{array}{cccc}1 & 2 & 3 & 4 \\ <10 & 11-1000 & 101-1000 & >1000 \\ \text { gm or ml)(per gm or ml)(per gm or } \mathrm{ml}) & \end{array}$

(per gm or $\mathrm{ml}$ )(per gm or $\mathrm{ml}$ )(per gm or $\mathrm{ml}$ )

\begin{tabular}{|c|c|c|c|c|c|c|c|c|c|c|}
\hline & & & $\begin{array}{l}\text { No.of } \\
\text { samples }\end{array}$ & $\% \cdot \mathrm{s}$ & $\begin{array}{l}\text { No.of } \\
\text { samples }\end{array}$ & $\begin{array}{ll}\% & 1 \\
& \mathrm{~s}\end{array}$ & $\begin{array}{l}\text { No. of } \\
\text { samples }\end{array}$ & $\% \mathrm{~N}$ & $\begin{array}{l}\text { of } \\
\text { ples }\end{array}$ & $\%$ \\
\hline & & Coliforms & 3 & 7.14 & 4 & 9.5 & 15 & 35.7 & 20 & 47.6 \\
\hline \multirow[t]{2}{*}{ Ice cream } & \multirow[t]{2}{*}{42} & E coli I & 9 & 21.4 & 6 & 14.2 & 13 & 30.9 & 14 & 33.3 \\
\hline & & Faecal Streptococci & 11 & 26.19 & 2 & 4.7 & 9 & 21.4 & 20 & 47.6 \\
\hline \multirow{3}{*}{$\begin{array}{l}\text { Other Desserts } \\
\text { Fruit salad } \\
\text { Woodapple cream }\end{array}$} & \multirow{3}{*}{26} & Coliforms & 3 & 11.5 & 7 & 26.9 & 14 & 53.8 & 2 & 7.6 \\
\hline & & E coli I & 9 & 34.6 & 11 & 42.3 & 6 & 23 & 0 & 0 \\
\hline & & Faecal Streptococci & 16 & 61.5 & 2 & 7.6 & 7 & 26.9 & 1. & 3.8 \\
\hline \multirow{3}{*}{ Pastries } & \multirow{3}{*}{37} & Coliforms & 32 & 86.4 & 3 & 8.1 & 1 & 2.7 & 1 & 2.7 \\
\hline & & E coli I & 35 & 94.5 & 0 & 0 & 1 & 2.7 & 1 & 2.7 \\
\hline & & Faecal Streptococci & 36 & 97.2 & 0 & 0 & 1 & 2.7 & 0 & 0 \\
\hline \multirow{3}{*}{ Fruit drinks } & \multirow{3}{*}{34} & Coliforms & 29 & 85.2 & 4 & 11.76 & 1 & 2.9 & 0 & $\mathbf{0}$ \\
\hline & & E coli I & 34 & 100 & 0 & 0 & 0 & 0 & 0 & 0 \\
\hline & & Faecal Streptococci & 32 & 86.4 & 1 & 2.9 & 1 & 2.9 & 0 & 0 \\
\hline \multirow{3}{*}{$\begin{array}{l}\text { Fermented } \\
\text { milk products }\end{array}$} & & Coliforms & 20 & 45.4 & 12 & 27.2 & 8 & 18.1 & 4 & 9 \\
\hline & & E coli I & \multicolumn{2}{|c|}{44100} & 0 & 0 & 0 & 0 & 0 & 0 \\
\hline & 44 & Faecal Streptococci & 20 & 45.4 & \multicolumn{2}{|c|}{818.1} & 8 & 18.1 & 8 & 18.1 \\
\hline
\end{tabular}

$\mathrm{A}<10$ B $11-100$ C $101-1000$ D $>1000$ Coliforms E Colitype I Faecal Streptococci

The faecal,indicator densities of the second group of food such as fruit salads, woodapple crean, etc are lower compared to ice cream. With this group of food (fruit salad etc) none of the samples showed $E$. coli I densities exceeding 1000/gram. 
In the third group of food that were investigated, which were pastries (rolls, patties, cutlets,etc), around 95 per cent of the samples indicated faecal streptococci and E. coli $I$ densities $<10 /$ gram.

The results of the 34 samples of fruit drinks show that 85 per cent of the samples belong to the 1 st category (Table1) where the indicator density is less than 10 with regard to coliforms and faecal streptococci. None of the fruit drink samples were positive for $E$. coli $I$. The $E$ coli I densities of all the samples of fermented milk products are below $10 /$ gram.

The distribution of the per centages of samples of the different types of food in the four categories A, B, C and D representing indicator densities $<10,11-100,101-$ 1000 and $>1000 /$ gram is illustrated in Figure I.

A greater percentage of the samples of ice cream fall into category $D$ with indicator densities $>1000$ /gram. A greater percentage of pastries and fermented milk products fall into category $\mathrm{A}$. In other types of desserts the samples are distributed in categories $\mathrm{A}, \mathrm{B}$ and $\mathrm{C}$.

The mean total viable count, the mean counts of the indicators E. coli I, coliforms and faecal streptococci and the $\mathrm{pH}$ range of the different types of food are shown in Table 2. Table 2. Mean total viable count, mean counts of $E$ coli $I$, coliforms and faecal streptococci and
the pH range of the different types of foods examined.

\begin{tabular}{|c|c|c|c|c|c|}
\hline Type of Food & $\begin{array}{l}\text { Mean total } \\
\text { viable count } \\
\text { at } 30^{\circ} \mathrm{C} \\
\text { (per gm or } \mathrm{ml} \text { ) }\end{array}$ & $\begin{array}{c}\text { Mean density } \\
\text { E coli I } \\
\text { (per gm or } m l)\end{array}$ & $\begin{array}{c}\text { Mean density } \\
\text { Coliforms } \\
\text { (per gm or ml) }\end{array}$ & $\begin{array}{c}\text { Mean density } \\
\text { Faecal } \\
\text { streptococci } \\
\text { (pergm or } \mathrm{ml} \text { ) }\end{array}$ & pH range \\
\hline Ice cream & $32 \times 10^{4}$ & 726 & 1436 & 1425 & $5.5-6.5$ \\
\hline $\begin{array}{l}\text { Fruit salad \& } \\
\text { Woodapple cream etc. }\end{array}$ & $651 \times 10^{2}$ & 173 & 423 & 258 & $3.1-3.7$ \\
\hline Pastries & $115 \times 10^{2}$ & 36 & 55 & 12 & - \\
\hline Fruit drinks & 280 & 0 & 8 & 10 & $2.1-2.7$ \\
\hline $\begin{array}{l}\text { Fermented } \\
\text { milk products }\end{array}$ & $342 \times 10^{7}$ & 112 & 202 & 439 & $3.2-3.8$ \\
\hline
\end{tabular}
food.

Ice cream shows the highest mean bacteral densities among the non-fermented

The $\mathrm{pH}$ ranges from 5.5 to 6.5 in ice cream. 


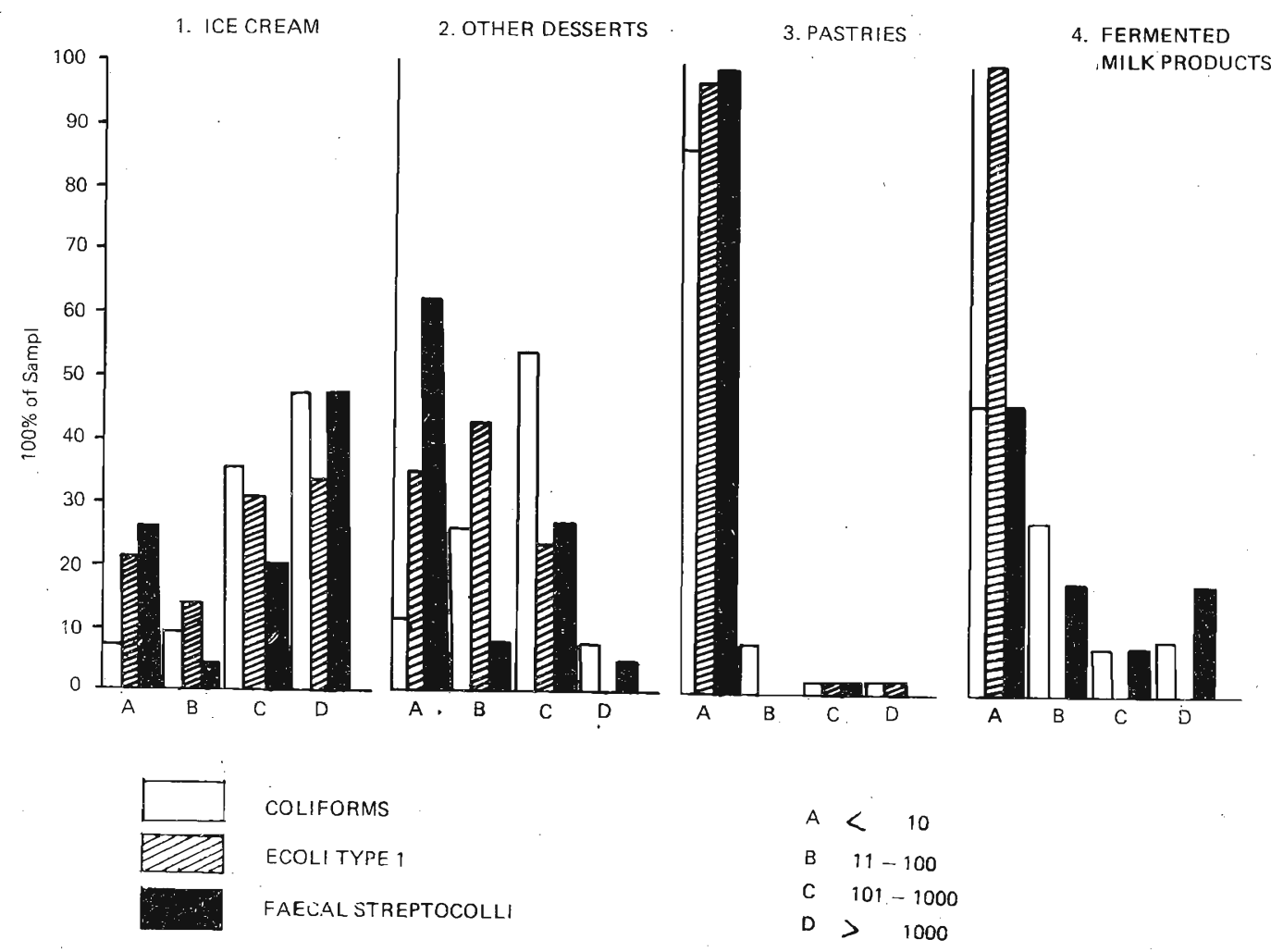

Figure 1. Distribution of the \% of samples in the 4 categories (A, B, C \& D) of Bacterial Indicator (Coliforms, E.coli type 1, and Faccal Streptococci) densities of the four different types ,of foods examined.

All food, except pastries show a significant difference between the mean E. coli I count and the mean faecal streptococci count. The faecal streptococci count is higher than the E.coli I count in these samples. None of the food samples examined were positive for salmonelia species.

\section{Discussion}

The results of this survey indicate the risk involved in the consumption of a variety of food and beverage served to the public within the limits of the Kandy Municipal Council. 
Ice cream is the most contaminated product of the five types of food under study. The hygienic quality of pastries and fruit drinks were found to be higher when compared to ice cream. The average bacterial counts in these food products serve as a basis of a general evaluation of the food.

In ice cream the average $E$. coli I count was found to be $726 \mathrm{per} \mathrm{ml}$. This reflects the poor hygienic standards of the majority of the food manufacturers. 33 per cent of the samples showed E. coli $I$ : densities higher than the above mentioned average. According to the Bureau of Standards, ice cream should be free of E. coli $I^{6}$ With the methodology used in the present study only 19 per cent of the samples of ice cream examined conformed to the standard laid down by the Bureau of Standards. The balance 81 per cent of the manufacturers need vast improvements in their hygienic standards.

The observed mean total viable count of ice cream at $30^{\circ} \mathrm{C}$ is slightly higher than the permissible total count 6 A high viable count at $30^{\circ} \mathrm{C}$ indicate contaminated raw materials, unsatisfactory sanitation, improper storage. This excludes food prepared by means of fermentation activity of living organisms.

The present study reveals that faecal bacterial indicator densities are highly dependent on the $\mathrm{pH}$ of a particular food. $\mathrm{A} \mathrm{pH}$ of 6-7 as in ice cream affords the environment for survival of a majority of bacteria. The survival of faecal bacteria are checked as the $\mathrm{pH}$ approaches 2-3. The $\mathrm{pH}$ of fruit drinks are in the range 2-3. Thus there was no difference in the bacterial densities of fruit drinks whether prepared on the pavement or inside reputable eating establishments.

The significance of micro-organisms used as indicators of faecal contamination of prepared food deserve some comment. The two species of intestinal bacteria which are of particular interest in food hygiene are $E$. coli $I$. and faecal streptococci, ${ }^{1}$ The numbers of faecal streptococci in faeces are usually lower than the number of $E$.coli $I^{3}$, but they differ in their sensitivity to various physiochemical actions. Due to the significant difference that was observed between faecal streptococci and E.coli I counts in ice cream and fermented milk products, it can be said that faecal streptococci survive better than $E$. coli $I$ in an acid environment and during freezing. In addition to the value of faecal streptococci as an indicator of faecal contamination in treated food, it has been shown that faecal streptococci has a food poisoning potential 2,5

In conclusion, it should be stated that production hygiene of food such as ice cream and fruit salads should be improved.

\section{Acknowledgements}

The authors gratefully acknowledge the financial assistance given by the Danish International Development Agency, Denmark. 
We wish to thank Mr. I. Goonewardena, the Food Inspector, Kandy Municipality for his help in the collection of samples.

\section{References}

1. BUTTIAUX, K. \& MOSSEL, D. D. A. (1961). The significance of various organisms of faecal origin infoods and drinking water. J. Appl. bacteriologyy. 353-36́4.

2. FUJIWARA, K., DEKIYA, T. \& BAMBA, K. (1956). Studies on the enterotoxin III, The production of enterotoxic substance by streptococcus zymogenes. Japan J. Bacteriology. 11:411-414.

3. KENNER, B. A.. CLARK, H. P. \& KABLER . P. W. (19.60). Faecal streptococci II, Quantitation of streptococci in faeces. Am. J. Public Health 50: 1553-59.

4. MEEDENIYA, K., TILlakARATNE, H. A., SilVAPATHAM, S. \& PASCAL. T. D. (1971). Bacteriological survey of Ice cream sold in the city of Colombo. Cey ${ }_{*}$ Associ. Advan, of Sci, Proc, of the 27th Ann. Sess, Part 1. 5. OSLER, A. G., BUCHBINDER, L. \& STEFFEN, G. S. (1948). Experimental enterococcal food poisoning in
man. Proc.Soc. Experimental Biol. Med. 67: 456-459.

6. SRI LANKA Standard 223, Bureau of Ceylon Standards. 